\title{
In Memory of Jagadīsh
}

\author{
Jeffrey S. Lidke ${ }^{1}$
}

Published online: 1 November 2019

(C) Springer Nature Switzerland AG 2019

Dr. Gerald James Larson was the proverbial gurus' guru, a true Jagadīsh, a teacher of teachers, a giant among men. Gerry, as he was affectionately known by his many students, colleagues, and friends, was a preeminent American Indologist and Sanskritist who taught at the University of California, Santa Barbara, and retired as Director of Indian Studies at Indiana University. He was a specialist in classical Yoga and Sāmkhya philosophy and wrote a number of books and articles in this area. I had the great good fortune of studying Sanskrit and Indian philosophy under Gerry's tutelage while pursuing my Ph.D. in Sanskrit and Indian Religions and Philosophies at the University of California at Santa Barbara from 1991 until 1996. I will always remember him for the rigor and passion with which he taught his advanced Sanskrit seminars at the University of California, Santa Barbara. Reading the Bhagavad Gìtā, Sämkhya-Kārikā, Mülamadhyamaka-Kārikā, Paramārtha-sāra, and a host of other classical works with him provided a foundation and experience that has benefited and enriched me ever since, both personally and professionally.

Gerry was also the minister at my first wedding, and in that context, I marveled at how fluidly he shifted from master Sanskritist to inspired officiant. Gerry taught me so much about so many things. It is because of Gerry that I was able to find the balance between my own life of faith and the value of engaging religious studies in an objective, scientific way. He modeled passionate scholarship and teaching that is grounded in the highest standards of critical analysis. And in this way, he showed me that my faith can serve my scholarship and vice versa. And he showed me that the world of academia and the world of spirituality need not dwell apart from each other. In fact, one of my most profound spiritual experiences occurred at the conclusion of Gerry's seminar on the Mülamadhyamaka-Kārikā. We had just completed reading Nagarjuna's complex analysis and negation of the logic of causation and were walking together to the parking lot under a moonlit night. My rational mind felt tied in knots. What exactly is being and non-being? How could it be that there is no "causation?" Like a Zen master Gerry knew my mind was ripe for the plucking. He turned to me and said, "You have to understand that the key is interconnectivity-pratityasamutpāda.

Jeffrey S. Lidke

jlidke@berry.edu

1 Religion and Philosophy, Berry College, Floyd County, GA, USA 
Everything is co-arising together, right now, in this moment. If everything is codependent with everything else, how can any one thing cause another to be? The reality of all things is right here right now in this moment. And that Reality is always right here, right now in this moment. Nothing causes that Reality to be and that Reality brings nothing else into existence other than Itself." Hearing these words, I remember that my mind literally became still for a moment, and as I looked up into the heavens, I felt a chill of excitement wash over my entire body. That momentary experience, grounded in a realization sparked by my guru's words, has shaped my outlook on life ever since. I have had many teachers over the years. None holds a place in my heart that is higher than that place in which I have enshrined Gerry. Truly, may he rest forever in peace. Wherever he is, may others continue to benefit from his whimsical smile and his inimitable ability to illumine and awaken minds. Thank you, Gerry, for your extraordinary commitment to not just the scholarly path but the path of being genuinely human. Aum namo'stute, Jagadish.

Publisher's Note Springer Nature remains neutral with regard to jurisdictional claims in published maps and institutional affiliations. 